\title{
AABOMYCIN A, A NEW ANTIBIOTIC. III
}

\section{TAXONOMIC STUDIES ON THE AABOMYCIN PRODUCING STRAIN, STREPTOMYCES HYGROSCOPICUS SUBSP. AABOMYCETICUS SEINO SUBSP. NOV.}

\author{
Akio Seino, Hideo Sugawara, Shiroh Shirato \\ and Tomomasa Misato* \\ Kaken Chemical Co., Ltd., Tokyo, Japan \\ * The Institute of Physical and Chemical Research, \\ Yamato-machi, Saitama Prefecture, Japan
}

(Received for publication December 23, 1969)

\begin{abstract}
A new subspecies of Streptomyces hygroscopicus was isolated from a peatysoil collected in Bibai, Hokkaido, Japan in July, 1965, and numbered as 32517. The isolate has been named Streptomyces hygroscopicus (JENSEN) W AKSMan et Henrici subsp. aabomyceticus Seino. Freeze-dried cultures of the type strain 325-17 have been deposited in the Fermentation Research Institute, Chiba, Japan and the American Type Culture Collection, Rockvill, Maryland, U. S. A. where they have been assigned accession numbers as FERM-P No. 166 and ATCC 21449, respectively.
\end{abstract}

A new antifungal antibiotic, aabomycin $\mathrm{A}$, has been isolated from fermented mashes of streptomycete strain 325-17 and its fermentative production, physico-chemical properties and biological activities reported previously ${ }^{1,2}$. The purpose of this paper is to describe the characteristics of Streptomyces hygroscopicus subsp. aabomyceticus SeIno subsp. nov. for valid publication according to Rules 11 and 12 of the International Code of Nomenclature of Bacteria, 1966). Additionally, the value of using the scanning electron microscope for characterization of fine structure of spore surface showing some irregularities is discussed. Scanning electron microscopy appears to be a useful alternate to preshadowed carbon repligraphy which requires rather complicated techniques and considerable operational time.

\section{Methods}

Most of the general procedures suggested by SHIRLing and Gortuieb ${ }^{4)}$ have been followed in this report except that inocula for various media consisted of thrice-washed mycelia. Other media, both synthetic and complex which are described by WAKsmaN ${ }^{5)}$ also were used. Difco Bacto Agar was employed as a soldifying agent for the various media except that Difco Noble Agar was used for the carbohydrate utilization test. Color comparisons of 21-day old cultures were made under a xenon lamp (Xenolight DL-500, Murakami Shikisai Kenkyusho, Tokyo, Japan) with reference to the Color Harmony Manual (CHM) 4th edition' ${ }^{6)}$ and noted, in succesion, by the CHM code number and CHM name. If the corresponding color name and number of the ISCC-NBS Method of Designating Colors (U.S. Department of Commerce, 1955) was defined, the ISCC-NBS color name and number also noted. Preshadowed carbon replicas of spores were prepared in accordance 
with the method reported by Dietz and $\mathrm{M}_{\mathrm{ATHEwS}}{ }^{7,8)}$ and carbon repligraphs were taken with a Hitachi HS-8 electronmicroscope. Gold pre-coated spores were prepared by following procedure for scanning electronmicrography:

1: Touch gently the surface of well-matured aerial growth of test organisms with Scotch Tape No. 465 pre-attached to a copper block.

2: Place the copper block in a vacuum jar and evacuated to less than $1 \mu \mathrm{Hg}$.

3 : Incline the copper block at an angle at $\pm 45^{\circ}$ from horizontal and at the same time rotate slowly during the period of shadowing with Au-metal.

4: Transfer the block to a JSM-2 scanning electronmicroscope (Japan Electron Optics Co., Ltd. Tokyo, Japan) and photograph.

\section{Results}

Micromorphology: Some media such as inorganic salts-starch agar (ISP), yeast extract-malt extract agar, BENNETT's agar, yeast extract-starch agar (yeast extract $2 \mathrm{~g}$, soluble starch $10 \mathrm{~g}$, agar $15 \mathrm{~g}$, distilled water $1,000 \mathrm{ml}, \mathrm{pH} \mathrm{7.0)}$ were useful for observation of micromorphology of this strain. Vegetative mycelia does not fragment into

Plate 1. Electronmicrograph of spores of strain 325-17 yeast extract-starch agar, 10 days $(\times 24,000 \times 1 / 2.5)$.

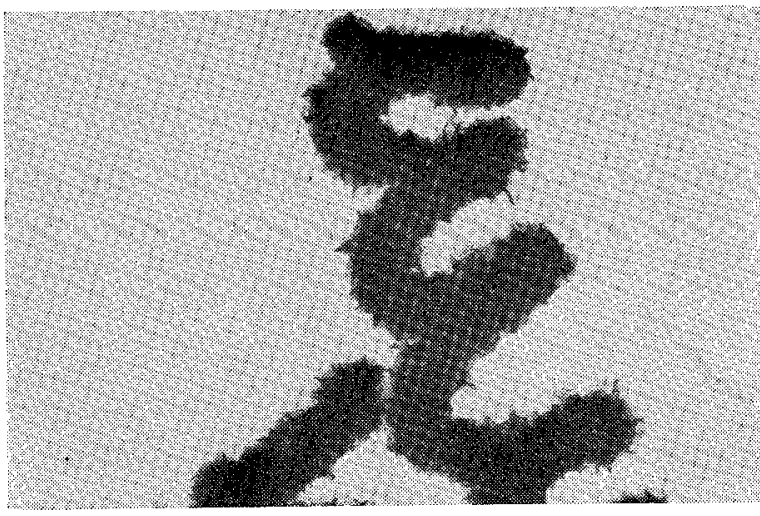

Plate 3. Scanning electron micrograph of spores at lower magnifications ( $\mathrm{Au}$ precoated, accelerating voltage 25 $\mathrm{KV}$, magnification $\times 3,000 \times 1 / 1.5)$.

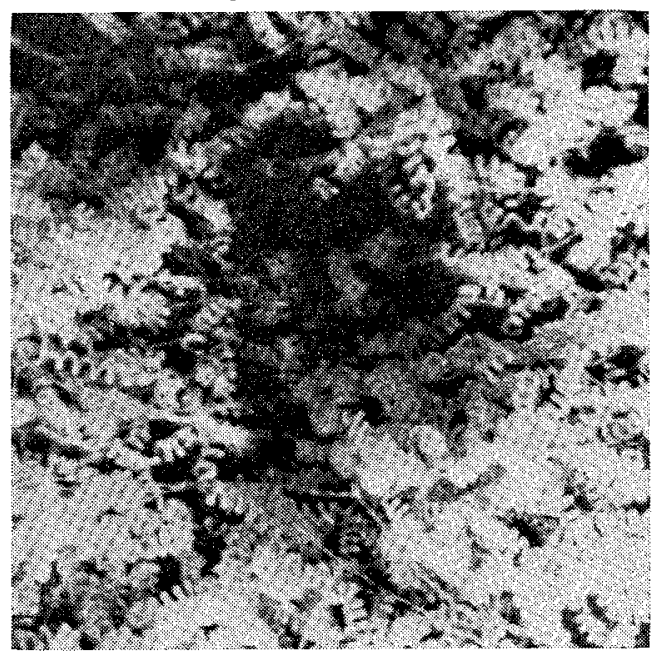

Plate 2. Carbon repligraph of spores of the strain $325-17$ (direct magnification $\times 22,000 \times 1 / 2.5)$

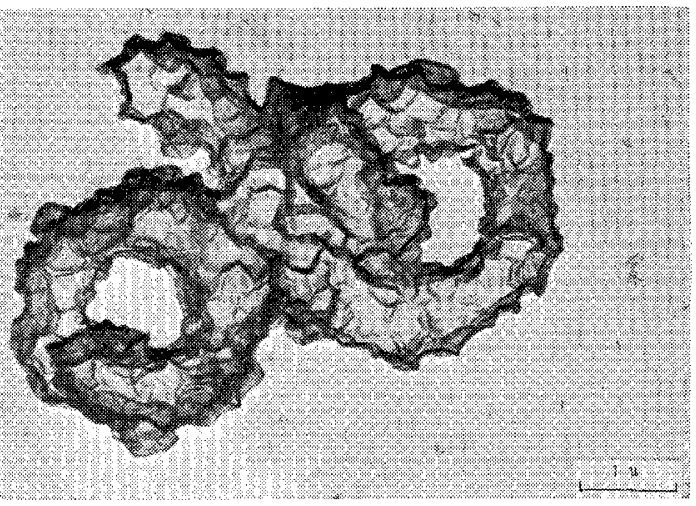

Plate 4. Scanning electron micrograph of spores at higher magnification $(\times 8,000 \times 1 / 1.5)$ (BENNETT's agar, 14 days, Au-precoated, accelerating voltage $25 \mathrm{KV}$ ).

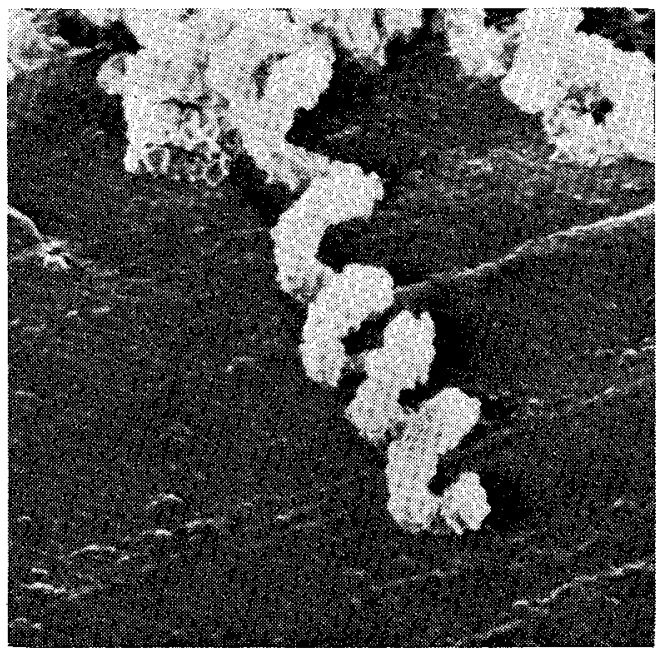


cocoid or bacillary elements in liquid media such as glucosenutrient broth etc. Spores (Electron micrograph, Plate 1); nonsegmented, covered with capsulelike membrane, ornamentation of surface is fairly irregular, possibly warty to coarsely spined. Carbon repligraph (Plate 2) and scanning electronmicrograph (Plates 3 and 4) show the surface of spores of this strain to be very rugose and indicate morphological similarity to spores of the Type I group of Streptomyces hygroscopicus reported by DiETz and MATHEWs ${ }^{7,8)}$. Sporophores; short side branches located along straight or flexuous main hyphae, terminating in closed coils (Spirales) of two or more volutions (Plate 5). Sporophores arranged singly, in pairs, or occasionally in tufts along axial mycelia, but no evidence of true verticillate branching. Average diameter of coils is $2.5 \mu$. There was no evidence of sporangia, zoospores, ball-like bodies ${ }^{9}$, coremia or sclerotia. Hygroscopic patches were observed with cultures on some media such as glucose-asparagine agar and asparagine-dextrose agar.

Cultural and physiological characteristics: Cultural and physiological studies were carried out at $28^{\circ} \mathrm{C}$ and the results read at 21 days unless otherwise stated.

Tables 1, 2 and 3 present results obtained in a series of various cultural and physiological tests of strain 325-17. These results place strain 325-17 within the Streptomyces hygroscopicus Type I group suggested by DiETz and MATHEWs ${ }^{7,8)}$. However, strain 325-17 differs from the description of S. hygroscopicus (WaKsman, 1961) as follows: (1) strain 325-17 does not produce yellowish soluble pigment in sucrosenitrate agar, whereas $S$. hygroscopicus produces such pigment; (2) strain 325-17 gives a weakly positive reaction in melanin formation agar and tyrosine agar ISP ; (3) strain 325-17 produces the antibiotic, aabomycin A, whereas any members of microorganisms belonging to the group of S. hygroscopicus do not produce aabomycin A, so far reported.

Two antibiotics, flavucidin and venturicidin which are similar to aabomycin A have been reported by SHIBATA et at. ${ }^{10)}$, and Rhodes et al. ${ }^{11}$ separately. However, no taxonomic details have been reported upon flavucidin-producer Streptomyces sp. No. 14402. On the other hand, RHoDEs et al. ${ }^{11)}$. briefly reported that venturicidin is produced by three distinct strains of streptomycete having a general resemblance to Streptomyces griseolus and S. halstedii and some affinity with S. xanthophaeus. As described above, aabomycin A producing strain 325-17 can be identified as one of the species belonging to S. hygroscopicus, thus strain 325-17 is easily differentiated from venturicidin producers. Therefore, the strain 325-17 represents a new subspecies of S. hygroscopicus whose name is proposed as Streptomyces hygroscopicus (JENSEN) 
Table 1. Cultural characteristics of strain $325-17$

\begin{tabular}{|c|c|c|c|c|}
\hline Medium & Growth & Aerial mycelium & Soluble pigment & Remarks \\
\hline $\begin{array}{l}\text { Sucrose-nitrate } \\
\text { agar plate }\end{array}$ & $\begin{array}{l}\text { Good, spreading, } \\
2 \text { ea (Light Wheat) }\end{array}$ & $\begin{array}{l}\text { Thin, powdery, almost } \\
\text { white with I ea (Light } \\
\text { Yellow) center }\end{array}$ & None & \\
\hline $\begin{array}{l}\text { Glycerol-nitrate } \\
\text { agar plate }\end{array}$ & $\begin{array}{l}\text { Good, spreading, } \\
2 \text { fb (Buff) (Light } \\
\text { Yellow, 86) }\end{array}$ & $\begin{array}{l}\text { Thin, powdery, white with } \\
g \text { (Gray) center }\end{array}$ & Pale Yellow & \\
\hline $\begin{array}{l}\text { Glucose- } \\
\text { asparagine } \\
\text { agar plate }\end{array}$ & $\begin{array}{l}\text { Good, spreading, } \\
2 \text { ea (Light Wheat) }\end{array}$ & $\begin{array}{l}\text { Abundant, powdery, } 3 \mathrm{fe} \\
\text { (Silver Gray) with } \\
\text { moistened patches }\end{array}$ & None & Hygroscopic \\
\hline $\begin{array}{l}\text { Asparagine- } \\
\text { dextrose agar } \\
\text { plate }\end{array}$ & $\begin{array}{l}\text { Same as glucose- } \\
\text { asparagine agar }\end{array}$ & $\begin{array}{l}\text { Abundant, powdery, } 5 \text { fe } \\
\text { (Ashes) (Light Grayish } \\
\text { Reddish Brown, } 45 \text { ) with } \\
\text { black moistened patches }\end{array}$ & None & Hygroscopic \\
\hline $\begin{array}{l}\text { Glycerol- } \\
\text { asparagine } \\
\text { agar plate }\end{array}$ & $\begin{array}{l}\text { Good, spreading, } \\
2 \text { ca (Light Ivory) } \\
\text { (Pale Yellow, 89) }\end{array}$ & $\begin{array}{l}\text { Thin, powdery, } 1 \mathrm{ba} \\
\text { (Yellow Tint) (Pale Yellow, } \\
89 \text { ) to } 3 \mathrm{dc} \text { (Natural) }\end{array}$ & $\begin{array}{l}\text { Very faintly } \\
\text { pink }\end{array}$ & \\
\hline $\begin{array}{l}\text { Glycerol- } \\
\text { calcium malate } \\
\text { agar plate }\end{array}$ & $\begin{array}{l}\text { Restricted, elevated } \\
2 \text { ic (Light Gold) }\end{array}$ & $\begin{array}{l}\text { Abundant, powdery, } 1 \text { ic } \\
\text { (Citron Yellow) to } 3 \text { ig } \\
\text { (Beige Brown) (Grayish } \\
\text { Yellowish Brown, 80) }\end{array}$ & None & $\begin{array}{l}\text { Calcium malate } \\
\text { partially } \\
\text { solubilized }\end{array}$ \\
\hline $\begin{array}{l}\text { Inorganic salts- } \\
\text { starch agar } \\
\text { plate (ISP) }\end{array}$ & $\begin{array}{l}\text { Abundant, } \\
\text { spreading, I la } \\
\text { (Lemon Yellow) }\end{array}$ & $\begin{array}{l}\text { Abundant, powdery, } 4 \mathrm{li} \\
\text { (Beaver) (Brownish Gray, } \\
64 \text { ) }\end{array}$ & Light Yellow & $\begin{array}{l}\text { Hydrolytic } \\
\text { activity is } \\
\text { positive }\end{array}$ \\
\hline $\begin{array}{l}\text { Tyrosine agar } \\
\text { plate (ISP) }\end{array}$ & $\begin{array}{l}\text { Good, elevated, } 3 \text { le } \\
\text { (Cinnamon) to } 4 \mathrm{nl} \\
\text { (Dark Brown) }\end{array}$ & $\begin{array}{l}\text { Abundant, powdery, } 4 \mathrm{li} \\
\text { (Beaver) (Brownish Gray, } \\
64 \text { ) }\end{array}$ & 3 le (Cinnamon) & $\begin{array}{l}\text { Tyrosinase } \\
\text { reaction } \\
\text { weakly positive }\end{array}$ \\
\hline $\begin{array}{l}\text { Yeast extract- } \\
\text { malt extract } \\
\text { agar plate } \\
\text { (ISP) }\end{array}$ & $\begin{array}{l}\text { Abundant, } 1 \text { ia } \\
\text { (Lemon Yellow) to } \\
\text { more dark colored }\end{array}$ & $\begin{array}{l}\text { Abundant, powdery, } 4 \mathrm{li} \\
\text { (Beaver) (Brownish Gray, } \\
64 \text { ) }\end{array}$ & Light yellow & \\
\hline $\begin{array}{l}\text { Oatmeal agar } \\
\text { plate (ISP) }\end{array}$ & $\begin{array}{l}\text { Good, restricted, } \\
\text { not elevated, } 1 \frac{1}{2} \mathrm{ca} \\
\text { (Cream) }\end{array}$ & $\begin{array}{l}\text { Good, powdery, } 4 \text { li (Beaver) } \\
\text { (Brownish Gray, 64) }\end{array}$ & None & \\
\hline $\begin{array}{l}\text { BENNETT's agar } \\
\text { plate }\end{array}$ & $\begin{array}{l}\text { Elevated, good, I ga } \\
\text { (Light Yellow) }\end{array}$ & $\begin{array}{l}\text { Abundant, powdery, nearly } \\
5 \text { fe (Ashes) (Light Grayish } \\
\text { Reddish Brown, 45) }\end{array}$ & $\begin{array}{l}1 \mathrm{ca} \text { (Lemon } \\
\text { Yellow) }\end{array}$ & \\
\hline $\begin{array}{l}\text { Yeast extract- } \\
\text { starch agar } \\
\text { plate }\end{array}$ & $\begin{array}{l}\text { Abündant, elevated, } \\
\text { spreading, } 1 \text { ga } \\
\text { (Light Yellow) with } \\
\text { dark colored center }\end{array}$ & $\begin{array}{l}\text { Abundant, powdery, 3ig } \\
\text { (Beige Brown)(Grayish } \\
\text { Yellowish Brown, 80) }\end{array}$ & Light Yellow & \\
\hline $\begin{array}{l}\text { Nutrient agar } \\
\text { (Difco Bacto } \\
\text { Nutrient Agar) }\end{array}$ & $\begin{array}{l}\text { Moderate, } 1 \frac{1}{2} \mathrm{ca} \\
\text { (Cream) }\end{array}$ & Good, powdery, white & None & $\begin{array}{l}\text { Non- } \\
\text { chromogenic }\end{array}$ \\
\hline
\end{tabular}

WAKSman et Henrici, 1948 subsp. aabomyceticus SeINo subsp. nov.

\section{Description of Streptomyces hygroscopicus (JENSEN) WAKSMAN et Henrici, 1948 subsp. aabomyceticus SeINo subspecies novis}
a. a. b. o. my. ce, ti. cus.
M. L. adj. of aabomycin

Micromorphology: vegetative mycelia never fragments into bacillary or coccoid elements, branched finely.

Sporophores: occur singly, in pairs or sometimes in whorl-like arrangement but not as true veticils and terminated in compact sinistrose coils with two or more volutions.

Spores: non-segmented, possibly warty or spiny, surface irregular and much folded.

Special characteristics: hygroscopic.

Color of vegetative mycelia: Light Wheat (CHM, 2 ea) with sucrose-nitrate agar.

Color of aerial mycelia: Beaver (CHM, 4 li) (Brownish Gray, ISCC-NBS, 64) with 
Table 2. Physiological reactions of strain $325-17$

\begin{tabular}{|c|c|c|}
\hline Test & Media employed & Response \\
\hline \multirow[t]{3}{*}{ Melanin formation } & $\begin{array}{l}\text { Peptone iron agar (Difco) } \\
+0.1 \% \text { yeast extract }\end{array}$ & Negative (4 days) \\
\hline & $\begin{array}{l}\text { Melanin formation agar } \\
\text { stab (WAKsMAN, No. 42) }\end{array}$ & $\begin{array}{l}\text { Doubtful (21 days) } \\
\text { Light brown }\end{array}$ \\
\hline & Tyrosine agar (ISP) & $\begin{array}{l}\text { Doubtful (21 days) } \\
\text { Light brown }\end{array}$ \\
\hline Tyrosinase reaction & Tyrosine agar (ISP) & Doubtful \\
\hline Xanthine decomposition & $\begin{array}{l}\text { Xanthine agar (Gordon \& } \\
\text { Mihm) }\end{array}$ & Negative \\
\hline $\begin{array}{l}\text { Hydrogen sulfide } \\
\text { production }\end{array}$ & $\begin{array}{l}\text { Peptone iron agar (Difco) } \\
+0.1 \% \text { yeast extract }\end{array}$ & $\begin{array}{l}\text { Negative } \\
\text { (over night) }\end{array}$ \\
\hline \multirow[t]{2}{*}{ Nitrate reduction } & Glucose-nitrate broth & Negative \\
\hline & Nitrate broth (Difco) & Negative \\
\hline Liquefaction of gelatin & $20 \%$ Difco Bacto Gelatin & Positive \\
\hline Liquefaction of serum & $\begin{array}{l}\text { Difco LöFFLER serum } \\
\text { medium }\end{array}$ & Positive \\
\hline Digestion of milk & $10 \%$ Difco Bacto skim milk & Positive \\
\hline Cellulolytic activity & $\begin{array}{l}\text { Filter paper }+ \text { CZAPEK broth } \\
\text { without carbon source }\end{array}$ & Negative \\
\hline Temperature range & BENNETT's agar, pH 7.0 & $\begin{array}{l}\text { No growth at } 5^{\circ} \mathrm{C} \\
\& 50^{\circ} \mathrm{C}\end{array}$ \\
\hline Oxygen requirement & $\begin{array}{l}\text { Glycerol nutrient broth } \\
\text { under } \mathrm{CO}_{2} \text { atmosphere }\end{array}$ & Aerobic \\
\hline
\end{tabular}

inorganic salts-starch agar ISP.

Chromogenicity: doubtful positive reactions with tyrosine agar and melanin formation agar and negative reaction with peptone-iron agar.

Soluble pigment other than melanoid: pale yellow with various media.

Physiological properties: starch, gelatin and milk are hydrolyzed; cellulolytic activity, xanthine decomposition, nitrate reduction and hydrogen sulfide production are negative; carbohydrate utilization patterns positive for most compounds tested.

Temperature relationship: mesophilic.

Oxygen relationship: aerobic.

Habitat: soil.

Antagonistic properties: produces aabomycin A.

Type strain: strain 325-17 is designated as the type of this new subspecies and has been deposited in the Fermentation Research Institute, Chiba, Japan and the American Type Culture Collection, Maryland, U. S. A. where they have been assigned accession numbers as FERM-P No. 166 and ATCC 21449, respectively.

\section{Discussion}

The advantages of the scanning electron microscope to perform a micromorphological examination upon the fine structure of actinomycetes has been discussed by WiLliams and DAVIES $^{12)}$. It have been reported that spore surfaces of S. hygroscopicus shows apparently wrinkled using carbon repligraphy with the usual transmission type electronmicroscope (Dietz and Mathews ${ }^{7,8)}$ ). Using adhesive Scotch Tape No. 465, specimens of S. hygroscopicus subsp. aabomyceticus were prepared simply by a direct printing method from petri dish cultures. The selection of a suitable adhesive has an important effect to resultant images. Probably, the adhesive, Scotch Tape No. 465, does not generate some undesirable 
refractions of primary- and secondary-electrons which disturb resultant images. Although, the scanning electronmicroscope has a disadvantage in markedly lower resolving power than the transmission type electronmicroscope, the direction of rotation of coils can be clearly observed at lower magnifications. However, even with scanning electron-micrography the segmentation of catenulate spores of strains 325-17 has not yet been observed. In scanning electron-micrography, a metalic coating of spore surfaces under higher vacuum is rather indispensable procedure for clear resultant images. The coating process, however, needing some carefulness is an undoubtedly defect in scanning electron-micrography. Because of the lower resolving power of the scanning electronmicroscope, the condition of the instrument also influences resultant images. In spite of the disadvantages, scanning electron-microscope can be very useful for observation of fine structure of spore surfaces, especially for characterization of strains belonging to the S. hygroscopicus Type I group, and for routine examination of sporophore morphology.

\section{Acknowledgement}

We are much indebted to Technical Research Lab., Fujitsu Laboratory's Ltd., Kawasaki, Japan and Naka Works, Hitachi Ltd., Katsuta, Japan for the scanning electronmicrography, the carbon repligraphy and transmission electronmicrography carried out in connection with this study.

\section{References}

1) Aizawa, S.; Y. Nakamura, S. Shirato, R. Taguchi, I. Yamagudhi \& T. Misato: Aabomycin A, a new antibiotic. I. Production, isolation and properties of aabomycin A. J. Antibiotics 22 : $457 \sim 462,1969$

2) Yamaguchi, I.; R. Taguch, K. T. Huang \& T. Mrsato: Aabomycin A, a new antibiotic. II. Biological studies on aabomycin A. J. Antibiotics $22: 463 \sim 466,1969$

3) Editorial Board of the Judicial Commission of the International Committee on Nomenclature of Bacteria. International code of nomenclature of bacteria. Intern. J. Syst. Bact. 16:459 490, 1966

4) Shirling, E. B. \& D. Gotrlieb : Methods for characterization of Streptomyces species. Intern. J. Syst. Bact. $16: 313 \sim 340,1966$

5) WaKsman, S. A. : The actinomycetes. Vol. II. Classification, identification and description genera and species. pp. 328 334. The Williams \& Wilkins Co., Baltimore, 1961

6) Color Harmony Manual, 4 th edition : Container Carporation of America, Chicago, U. S. A. 1958

7) Dietz, A. \& J. Mathews: Taxonomy by carbon replication. I. An examination of Streptomyces hygroscopicus. Appl. Microbiol. 10:258 263, 1962

8) Dietz, A. \& J. Mathews : Taxonomy by carbon replication. Il. Examination of eight additional cultures of Streptomyces hygroscopicus. Appl. Microbiol. 16:935 941, 1968

9) Nind, T.; K. Hamamoto, T. Tsuruoka \& T. Hara: Taxonomic studies on a new Streptomyces producing both blasticidin S and 8-azaguanine. Sci. Rep. Meiji Seika Kaisha 6:27 38,1963

10) Shibata, M.; K. Nakazawa, A. Mryake, M. Inove, J. Terumichi \& H. Kawashima : New antibiotic, flavucidin, produced by a Streptomyces No. 14420. Ann. Rep. Takeda Res. Lab. $17: 16 \sim 18$, 1958 (in Japanese)

11) Rhodes, A.; K. H. Fantes, B. Boothroyd, M. P. McGonagle \& R. Cross: Venturicidin, a new antifungal antibiotic of potential value in agriculture. Nature $192: 952 \sim 954,1961$

12) Williams, S. T. \& F. L. Davies: Use a scanning electron microscope for the examination of actinomycetes. J. Gen. Microbiol. $48: 171 \sim 177,1967$ 